\title{
The Validation of Learning Management System In Mechanics Instruction for Prospective Physics Teachers
}

\author{
Ni Made Yeni Suranti ${ }^{1 *}$, Gunawan ${ }^{2}$, Ahmad Harjono ${ }^{2}$, Agus Ramdani ${ }^{1}$ \\ ${ }^{1}$ Program Studi Magister Pendidikan IPA, Universitas Mataram \\ ${ }^{2}$ Program Studi Pendidikan Fisika, Universitas Mataram \\ *Email: surantiyeni@unram.ac.id
}

Received: 12 Maret 2020;

Accepted: 19 April 2020;

Published: 24 April 2020

DOI: http://dx.doi.org/10.29303/jpft.v6i1.1745

\begin{abstract}
The quality of education can be improved through the improvement of learning devices. Learning devices are important to facilitate students' conceptual understanding and creativity. Utilization of information technology such as the use of learning management systems (LMS) can make learning effective. This study aimed to produce LMS devices in mechanics instruction that are feasible to use and can improve students' conceptual understanding and creativity. This study is a research and development using a four 4-D model namely, define, design, develop, and disseminate. This research focused only on the stages of define, design and develop. In the develop phase, the learning device validation process was carried out. The instrument of validation used was a validation sheet. The validity test was conducted by 3 expert lecturers and it was concluded that the device developed was suitable for learning. Expert assessment on learning devices is reliable, which means there are no significant differences in each assessment. Criticisms and suggestions given are used as material for revision/improvement so that learning devices are obtained that are intact and ready to be used for learning.
\end{abstract}

Keywords: learning management system; conceptual understanding; creativity; mechanics; blended learning

\section{INTRODUCTION}

The era of industrial revolution 4.0 requires education to change and develop a lot to create an advanced generation, that can think at a high level and can compete globally. Students need to be creative and innovative in balancing change to be competitive (Puncreobutr, 2016). Educators as a major component in education must be able to develop their competencies to face the 4.0 era. The improved quality of education can be addressed through improved learning systems in schools or colleges. Learning process, especially in physics education can be done by developing innovative learning devices.

Learning devices are a collection of learning resources that can help the implementation of learning so that it becomes more effective and competitive (Prasetyo \& Gymnastics, 2011). Physics learning devices that are well prepared will be able to improve the students' understanding of concepts and thinking skills (Sahidu et al. 2018). One of the innovative learning tools is information technologyoriented devices. A learning management system (LMS) is a learning system that utilizes information technology. In the process, students $\log$ in and then receive learning briefly, then solve quiz questions (Anderson, et al. 1974). LMS is used as the most effective approach (Kakasevski et al. 2008) and is efficiently used in learning (Szabo, 2002).

One of the right models used in LMS is blended learning. Blended learning is one of the effective models to accommodate students to develop their knowledge through face to face and online (Alammary, 2014). The application of offline and online systems in learning can facilitate the needs of its users (Al-Azawei et al. 2017). Blended learning with LMS Moodle can facilitate students in 
collaborating and increasing their conceptual understanding (Psycharis, et al. 2013). Conceptual understanding includes the process of categorizing and classifying some complex knowledge so that it can explain an event (Anderson \& Krathwohl, 2015). According to Dahar (2011), conceptual understanding is an ability in understanding the topic of learning scientifically then it can be applied in everyday life. Efforts must be made to master the concept of understanding and re-applying much information from a subject topic (Silaban, 2014).

The learning devices to be used need to be well prepared so that their implementation can develop conceptual understanding. Besides being able to improve the mastery of physics concepts, learning must also be able to increase creativity. According to Nisrina et al. (2016) conceptual understanding related to creativity. If the level of conceptual understanding in physics is low, then the level of creativity will also low. Rawat et al. (2012) stated that creativity can be developed with creative learning as well.

Wyse \& Ferrari (2015) revealed that creativity is a learning ability that can express new things obtained from the learning process. Subali research results (2011) state that the creativity of students in science learning shows the basic skills, processing and investigating skills that are still low. This illustrates that teachers in schools are not optimal in developing the creativity of students. According to Marisi (2007), low creativity is also caused by the low ability of educators to measure creativity.

The process of learning physics in several institutions must be improved, especially to increase the creativity of prospective teachers. Learning tools in some LPTKs still rarely use information technology as an effective and innovative learning aid. Therefore, given the lack of effective learning devices, it is necessary to develop an LMS device with a blended model as a competent innovation. LMSoriented learning devices are expected to improve students' conceptual understanding and creativity in mechanics. LMS in mechanics. LMS mechanics is equipped with various features that support the learning process such as teaching materials, virtual media, conceptual understanding test, and creativity test. The learning device developed must go through a validation process. Validation is done to prove the device developed is suitable for learning and able to overcome problems related to learning mechanics.

\section{RESEARCH METHOD}

This study is a research and development. The stages of development research used were the 4-D model from Thiagarajan et al. (1974). Development of learning devices was used the 4-D model with the assumption that 4-D model learning devices are more concise and simpler. The development of LMS devices consisted of 4 stages of development namely define, design, develop and disseminate. At the development stage, a validation test was carried out by 3 expert validators. The validation data analysis technique used the following equation by Arikunto (2010).

$$
\begin{gathered}
\mathrm{PV}=\frac{\text { score from validator }}{\text { total score }} \times 100 \% \\
* \mathrm{PV}=\text { percentage of validatity }
\end{gathered}
$$

Based on the percentage of validation obtained, the validity criteria based on Arikunto (2010) are set as in Table 1.

Table 1. Validity Criteria

\begin{tabular}{cl}
\hline $\begin{array}{l}\text { Range of Percentage } \\
\text { Value (\%) }\end{array}$ & Category \\
\hline $0-20$ & Strongly not valid \\
$21-40$ & Less Valid \\
$41-60$ & Enough Valid \\
$61-80$ & Valid \\
$81-100$ & Strongly Valid \\
\hline
\end{tabular}


The instrument used was a validation sheet. The validation sheet was filled in by expert validators who examine and assess learning devices developed by researchers. The aspects assessed by the validator were the content of learning devices, presentation, systematic writing and the use of language in the learning devices. The reliability calculation of the LMS instrument validation sheet instrument is based on the interobserver agreement obtained from the statistical analysis of the Percentage of Agreement (PA) (Borich, 1994).

$$
P A=1-\frac{A-B}{A+B} \times 100
$$

The results are reliable if it has a percentage of $\geq 75 \%$ (Borich, 1994).

\section{RESULTS AND DISCUSSION}

In this research, the LMS tool was successfully developed in learning mechanics to improve conceptual understanding and creativity of students This research used 4-D model that focused on the develop stage, which includes the validity test. Development of learning devices in advance through the stages of define and design.

At the define stage, brainstorming, content analysis, and literature review were appropriate. Many parts were decided in this section, such as the equipment needed, the number of instruments to be developed, the type of instrument chosen, the material of the mechanics concept, and who will be involved or involved in this research. Besides, an analysis of students, task analysis, concept analysis and specifications of learning objectives were carried out. The main purpose of the design stage was to prepare prototype devices such as test preparation, media selection, and format selection. At this stage also produced the first draft of the device which includes RPS (Rencana Pembelajaran Semester) or semester learning plan, RTM (Rancangan Tugas Mahasiswa) or student assignment design, SAP (Satuan Acara Perkuliahan) or lecture unit, LKM (Lembar Kerja Mahasiswa) or worksheet, teaching materials, and test instruments. The device is integrated into the LMS so that the learning process uses a blended learning model.

In the design stage, the e-learning display was also designed using Moodle LMS and uploaded some device documents such as teaching materials, LKM, test questions, videos, and virtual simulations to support the learning process. The e-learning system is also equipped with chat or discussion room features that make it easy for students to discuss or express ideas related to the topic being studied. The following is a display of e-learning mechanics that can be accessed by students.

The log-in stage was designed so that students can create an account independently. This is intended so that students remember the username and password that was created to log into the elearning site. The test questions designed are in the form of e-assessment. Conceptual understanding test is in multiple choice questions. Students who carry out the test will get feedback directly after the test ends. Creativity test takes the form of description. In the verbal and procedural creativity test, students will directly type their answers in the columns provided on the LMS. While in numerical and figural creativity tests, students are asked to write and draw their answers on a piece of paper and then they will be photographed using their respective smartphone cameras to be uploaded to the columns available at LMS. The following is an e-assessment display of mastery of concepts and creativity. 


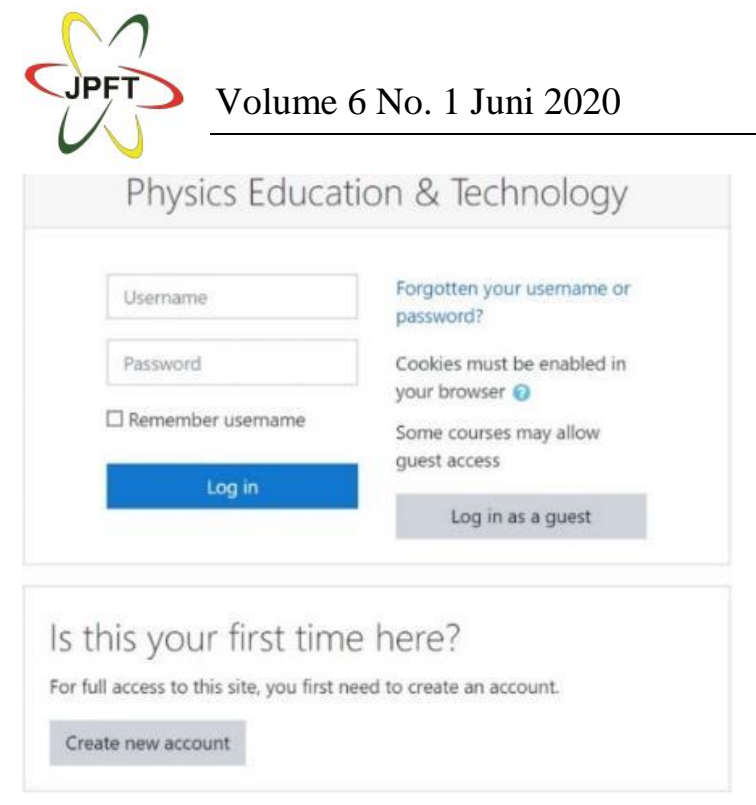

(a)
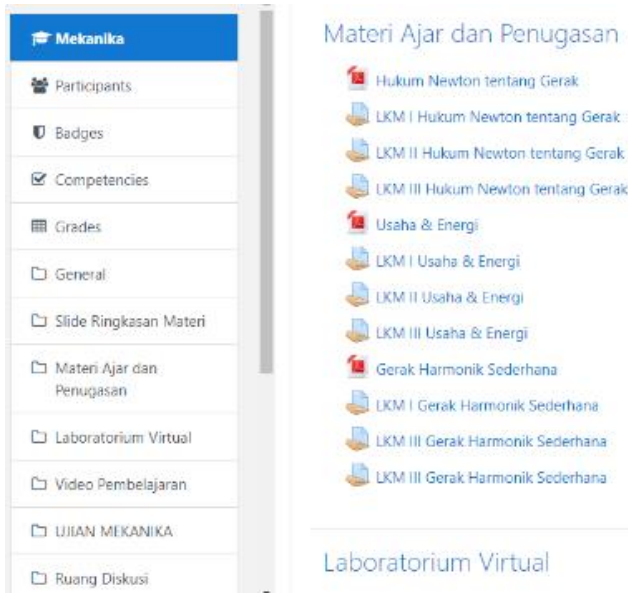

(b)

Figure 1. The Display of Mechanics ELearning (a) Log-in System; (b) Content of Elearning

In the e-learning design process, there were suggestions for improvement such as creating some practice test packages that students use to study anywhere and anytime. Also, the images used in e-learning should be of high quality so that they appear more clearly. The LMS devices that was produced as an initial draft has gone through a validation test process by three expert validators who reviewed and reviewed aspects of content, presentation and learning activities.
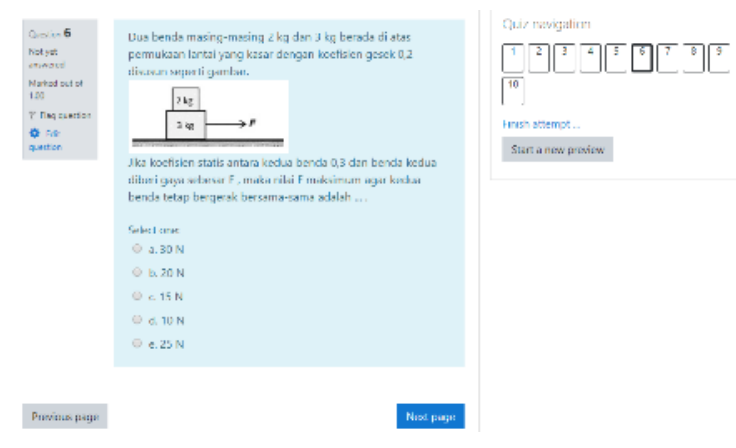

(a)

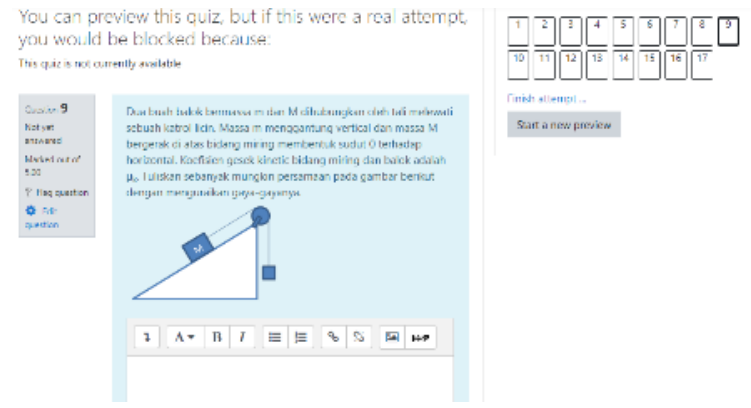

(b)

Figure 2. The Display of E-Assessment, (a) Conceptual Understanding Test; (b) Creativity Test

Based on the validation results, it was found that the learning device developed was included in the category of validity level that is feasible to use in learning mechanics. The following in Table 2 summarizes the results of validation by three expert validators in each component of the learning device.

Table 2. The Result of Validation Test

\begin{tabular}{lcl}
\hline \multicolumn{1}{c}{$\begin{array}{c}\text { Learning } \\
\text { Devices }\end{array}$} & $\begin{array}{c}\text { Percentage of } \\
\text { Validation } \\
(\boldsymbol{\%})\end{array}$ & Criteria \\
\hline RPS & 81.80 & Strongly valid \\
RTM & 80.74 & Valid \\
SAP & 85.19 & Strongly valid \\
LKM & 86.00 & Strongly valid \\
Teaching & 78.00 & Valid \\
Material & & \\
Conceptual & 76.89 & Valid \\
Understanding & & \\
Test & & \\
Creativity & 85.61 & Strongly valid \\
Test & & \\
\hline
\end{tabular}


Table 3. The Result of Reliability Test

\begin{tabular}{lcl}
\hline $\begin{array}{l}\text { Learning } \\
\text { Devices }\end{array}$ & $\begin{array}{c}\text { Percentage } \\
\text { of } \\
\text { Agreement } \\
(\boldsymbol{\%})\end{array}$ & Category \\
\hline RPS & 98.52 & Reliable \\
RTM & 99.18 & Reliable \\
SAP & 97.18 & Reliable \\
LKM & 95.09 & Reliable \\
Teaching & 94.46 & Reliable \\
Material & & \\
Conceptual & 89.13 & Reliable \\
Understanding & & \\
Test & & \\
Creativity & 93.65 & Reliable \\
Test & & \\
\hline
\end{tabular}

Table 2 concluded that the value of validity of each component of the developed learning device meets valid and strongly valid categories because the average validity score is in the interval $61-80$ and $81-100$. The RPS validity percentage of $81.80 \%$ in the strongly valid category. However, there were some suugestions to improve the developed RPS. Comments and suggestions from expert validators that need to be added information about the limitations of the material listed in the RPS making it easier for readers to study it. The RPS that was developed was not for one semester of learning but was limited to only three mechanics topics namely Newton's Law of Motion, Work and Energy, and Simple Harmonic Motion. The RPS that was compiled must also be adjusted to the guidelines for the preparation of RPS in tertiary institutions. In addition to the course achievements, the final abilities and indicators formulated need to be adjusted to the agreed Indonesian National Qualification Framework. The keywords of workability in level 6 must be well facilitated in their study of applying, studying, designing, utilizing science and technology in solving procedural problems.

In addition to the RPS in this study, RTM was also developed. RTM or student assignments were arranged to accommodate student assignments so that they are planned and targeted according to the developed RPS. The percentage of results of RTM validation is $80.74 \%$. This means that the RTM developed is suitable for use in learning mechanics. Criticisms and suggestions were given by expert validators namely the purpose of the task must be adjusted to the variables to be examined. The assignments given must also be following the material available and not overburden students. Also, the RTM identity needs to include the name of the material related tasks, for example, the material Newton's Law of Motion, Work and Energy, and Simple Harmonic Motion.

In the SAP component, the percentage analysis result is $85.19 \%$ with a strongly valid category. Learning objectives include indicators of creativity. Expert validators advise that at the core activities, bring up activities that develop creativity for example when asking questions, discussing. All content on SAP must strengthen its creativity variable. Whereas in LKM with a very decent percentage of validity category there are also some suggestions from expert validators, namely the learning objectives of SAP and LKM must be adjusted. The questions listed on the LKM should also be added to conceptual questions so that the mastery of student concepts can be facilitated properly.

Teaching material with a validation percentage of $78 \%$, which is in the appropriate category, also needs to be revised. Expert validators advise that teaching materials should include learning indicators. Besides, the images displayed must be consistent with the name of the image and in black and white. This is so that students can understand images well and the focus of students not only on the images but also on the content of the material.

The evaluation instruments developed in this study include the instrument of conceptual understanding and instruments of creativity. Conceptual understanding is 
cognitive ability according to Bloom's revised edition of taxonomy from $\mathrm{C} 1$ to $\mathrm{C} 6$. The categories are $\mathrm{C} 1$ (remember), $\mathrm{C} 2$ (understand), C3 (apply), C4 (analyze), C5 (evaluate), and C6 (create). The development of instrument of conceptual understanding in this study was categorized as feasible to be used with the note that it was necessary to hold a revision related to the content of the test questions. Conceptual questions should be reproduced so that the questions about analyzing and formulating equations do not dominate too much.

The creativity instruments developed were as many as 4 types of tests including verbal, figural, numerical and procedural creativity tests. The fourth creativity has 4 indicators scattered on the test questions. The creativity test indicators used are, according to Guilford (1950), covering fluency, flexibility, originality, elaboration (developing ideas in detail). The percentage of validation instruments for creativity is in the very feasible category. There is a validator's suggestion to make a creativity assessment sheet during the learning process that includes each of the creativity indicators.

Based on the validation results by experts, learning devices developed were suitable for use in learning mechanics. Some of the suggestions given by each validator are used as materials for improving the learning devices to produce the second draft that is better than before. The reliability of each expert's assessment of the learning device was also analyzed to determine the significance of the difference in the results of each expert's assessment. Based on the data analysis of the percentage of agreement in Table 3, it can be concluded that the expert's assessment of the learning devices is reliable, there is no significant difference. This is indicated by the results of the percentage of agreement for each component $\geqslant 75 \%$.
E-learning mechanics can be used to share learning resources, discuss, deliver announcements, give assignments and examinations, and provide assessments. Students can also access material, practice questions and collect assignments. In the learning process, the device developed refers to the blended learning model. Similar research has also been conducted by Herayanti et al. (2017) that Moodle-based learning devices are appropriate for use in learning in tertiary institutions. Sahidu et al. (2017) research results on the use of LMS also concluded that the development of the Moodle-based LMS-based e-assessment model can help students evaluate their learning outcomes. This model can also help provide motivation and problem-solving in learning.

\section{CONCLUSION}

LMS tools in learning Mechanics that are developed obtain valid results after the testing process by an expert validator. Criticisms and suggestions by the validator are used as material for repairing the device. Each expert's evaluation of the components of the LMS device is reliable. Besides, the content in the LMS devices that were developed was following the preparation guidelines and by the Mechanics concept. Some suggestions that researchers can propose are that the content in the device is enriched with virtual simulations that can be accessed easily. Also, it is expected that the development of e-learning based on Android will be more accessible in applications on smartphones.

\section{REFERENCES}

Al-Azawei, A., Parslow, P., \& Lundqvist, K. (2017). Investigating the effect of learning styles in a blended e-learning system: An extension of the technology acceptance model (TAM). 
Australasian Journal of Educational Technology, 33(2).

Alammary, A., Sheard, J., \& Carbone, A. (2014). Blended Learning in Higher Education: Three Different Design Approaches. Australasian Journal of Educational Technology, 30(4).

Anderson, T. H., Anderson, R. C., Dalgaard, B. R., Wietecha, E. J., Biddle, W. B., Paden, D. W., ... \& Klemt, L. L. (1974). A computer based study management system. Educational Psychologist, 11(1), 36-45.

Anderson, L. W., \& Krathwohl, D. R. (2015). Kerangka Landasan untuk Pembelajaran, Pengajaran, dan Asesmen: Revisi Taksonomi Pendidikan Bloom. Diterjemahkan oleh Agung Prihantoro. Yogyakarta: Pustaka pelajar.

Arikunto.S. (2010). Manajemen Penelitian. Jakarta : Rineka Cipta.

Borich, G. D. (1994). Observation skills for effective teaching. New York.

Cavus, N., Uzunboylu, H., \& Ibrahim, D. (2007). Assessing the success rate of students using a learning management system together with a collaborative tool in web-based teaching of programming languages. Journal of educational computing research, 36(3), 301-321.

Dahar, R. W. (2011). Teori-teori Belajar dan Pembelajaran. Jakarta: Erlangga.

Guilford, J. P. (1950). Creativity. American psychology.

Herayanti, L., Fuaddunnazmi, M., \& Habibi, H. (2017). Pengembangan Media Pembelajaran Berbasis Moodle pada Mata Kuliah Fisika Dasar. Jurnal Pendidikan Fisika dan Teknologi, 1(3), 205-209.

Kakasevski, G., Mihajlov, M., Arsenovski, S., \& Chungurski, S. (2008). Evaluating Usability in Learning Management System Moodle. In Information Technology Interfaces,
2008. ITI 2008. 30th International Conference on (pp. 613-618). IEEE.

Marisi, A. K. (2007). "Efektivitas Model Pengukuran Kreativitas dalam Pembelajaran Hemisphere Kanas (HK) untuk Meningkatkan Kreativitas Siswa Kelas V dalam Mata Pelajaran IPA di Sekolah Dasar". Jurnal Penelitian dan Evaluasi Pendidikan, 10(2), 169-190.

Nisrina, N., Gunawan, G., \& Harjono, A. (2016). Pembelajaran Kooperatif dengan Media Virtual untuk Peningkatan Penguasaan Konsep Fluida Statis Siswa. Jurnal Pendidikan Fisika dan Teknologi, 2(2), 66-72.

Prasetyo, Z. K., \& Senam, W. (2011). Pengembangan perangkat pembelajaran sains terpadu untuk meningkatkan kognitif, keterampilan proses, kreativitas serta menerapkan konsep ilmiah peserta didik SMP. Program Pascasarjana Universitas Negeri Yogyakarta.

Psycharis, S., Chalatzoglidis, G., \& Kalogiannakis, M. (2013). Moodle as a learning environment in promoting conceptual understanding for secondary school students. Eurasia Journal of Mathematics, Science \& Technology Education, 9(1), 11-21.

Puncreobutr, V. (2016). Education 4.0: New challenge of learning. St. Theresa Journal of Humanities and Social Sciences, 2(2).

Rawat, K. J., Qazi, W., \& Hamid, S. (2012). "Creativity and Education". Academic Research International, 2(2), 264-275.

Sahidu, H., Gunawan, G., Indriaturrahmi, I., \& Astutik, F. (2017). Desain Sistem EAssessment pada Pembelajaran Fisika di LPTK. Jurnal Pendidikan Fisika dan Teknologi, 3(2), 265-270.

Sahidu, H., Gunawan, G., Rokhmat, J., \& Rahayu, S. 2018. Pengembangan Perangkat Pembelajaran Fisika Berorientasi Pada Kreativitas Calon 
Guru. Jurnal Pendidikan Fisika dan Teknologi, 4(1), 1-6.

Silaban, B. 2014. Hubungan antara Penguasaan Konsep Fisika dan Kreativitas dengan Kemampuan Memecahkan Masalah pada Materi Pokok Listrik Statis. Jurnal Penelitian Bidang Pendidikan. 1 (20): 65-75.

Subali, B. 2011. Pengukuran Kreativitas Keterampilan Proses Sains dalam Konteks Assessment for Learning. Jurnal Cakrawala Pendidikan, 1(1).

Szabo, M. 2002. CMI Theory and Practice: Historical Roots of Learning Managment Systems. In M. Driscoll \& T. Reeves (Eds.), Proceedings of ELearn 2002--World Conference on ELearning in Corporate, Government, Healthcare, and Higher Education (pp. 929-936).

Thiagarajan, S., Semmel, D. S., \& Semmel, M. I. 1974. Instructional Development For Training Teachers of Exceptional Children.

Wyse, D., \& Ferrari, A. 2015. "Creativity and Education: Comparing The National Curricula of The States of The European Union and The United Kingdom". British Educational Research Journal,41(1), 3047.NCTM. (2000). Principles and standards for school mathematics. Reston, VA: Author. 